論文内容要旨

多軸鍛造法を用いた超微細粒純チタンの機械的特性と生物学的応答

神奈川歯科大学大学院歯学研究科

咀嚼機能制御補綴学講座伊東 佑輔

（指 導：木本 克彦 教授） 


\section{論 文内容要旨}

チタン材料は優れた機械的特性、生体適合性ならびに耐腐食性などから歯科材料として 使用されている。現在、純チタンは機械的強度が劣るため、チタン合金の開発が進められ 臨床において使用されている。しかしながら、チタン合金は生物学的性質に問題を有して おり、インプラント材料としては純チタンの機械的性質を向上させることが必要である。 今回、金属加工法の一手法である多軸鍛造法（MDK 法）を用いて新たな純チタン材料を開発 し、加えて新たな表面処理法と細胞応答の評価を行った。

試料として、Grade 2 純チタン（CCG-Ti）と、これに MDF 法を行った純チタン（UFG-Ti） の 2 種類とした。機械的特性として Vickers 硬さ、引張強さおよび弾性率を測定し、光学 顕微鏡ならびに電界放出型透過顕微鏡にて表面観察も行った。また、硫酸処理による表面 構造の変化を観察し、さらに骨芽様細胞によるチタン表面への初期接着と増殖性について 評価した。

その結果、UFG-Ti の機械的特性は CCG-Ti に比べて有意に高い引張強さと表面硬さ、低い 弾性率を示した（p<0.05）。表面観察においては、UFG-Ti では超微結晶粒組織で平均粒径は $100 \mathrm{~nm}$ 以下であった。また、酸処理後の表面構造は CCG-Ti では孔が不規則な方向であった が、UFG-Ti では規則性のある小孔が観察され、表面粗さと接触角も有意に低かった $(\mathrm{p}<0.05)$ 。 また、細胞応答では UFG-Ti は CCG-Ti と比べて増加傾向が強かった。

本研究から結果から、MDF 法により得られた新たな純チタン UFG-Ti と、そこに新たに開 発した酸処理法により、インプラント体に適した機械的特性と表面性状が得られる可能性 が示唆された。 